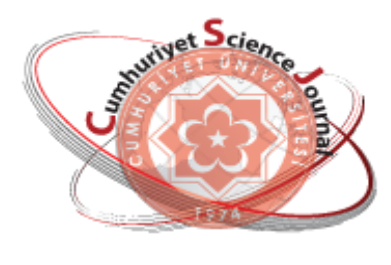

e-ISSN: $2587-246 X$

ISSN : 2587-2680

\section{Cumburisy at Seionce Journal esy}

Cumhuriyet Sci. J., Vol.40-1(2019) 162-169

\title{
Sb-Contribution Influence on the Characteristics of Spray-Coated $\mathrm{SnO}_{2}$
}

\author{
Güven TURGUTD
}

Erzurum Technical University, Faculty of Sciences, Erzurum, TURKEY

Received: 02.07.2017; Accepted: 14.01.2019

http://dx.doi.org/10.17776/csj.512892

\begin{abstract}
This work presents that the impact of Sb-additive on the crystalline, morphological, optical, and electrical features of $\mathrm{SnO}_{2}$. Sb-incorporated samples were fabricated on glass substrates with spray pyrolysis. Pyramidal and polyhedron shaped tetragonal Sb-introduced $\mathrm{SnO}_{2}$ grains were identified with XRD and SEM analysis. The degenerate $n$-type character for films was determined by electrical and optical characterizations. The resistivity and sheet resistance values initially decreased with Sb-content until $1.5 \mathrm{wt} \%$, then they increased with further Sb-level. However, carrier concentration increased with $2.5 \mathrm{wt}$. \% Sb-contribution, then it started to goes down with $3.5 \mathrm{wt}$. \%. The optical band-gap values of samples had a decreasing tendency with $\mathrm{Sb}$-doping. From the results obtained in the present study, it is said that $\mathrm{Sb}$-incorporated tin oxide films can be utilized in optoelectronic implements.
\end{abstract}

Keywords: Spray Pyrolysis, SnO2, Sb-doping, Electrical properties.

\section{Isıl Püskürtme Yöntemi ile Büyütülen $\mathrm{SnO}_{2}$ nin Karakteristik Özelliklerine Sb-Katkısının Etkisi}

\begin{abstract}
Özet. $\mathrm{Bu}$ çalışma Sb-katkısının $\mathrm{SnO}_{2}$ nin kristal, yüzeysel, optik ve elektriksel özelliklerine etkisini sunmaktadır. Sb katkılı numuneler 1sıl püskürtme yöntemi ile cam altlıklar üzerine büyütmüş̧ür. Piramit ve çok yüzlü şekilli tetragonal $\mathrm{Sb}$ katkılı $\mathrm{SnO}_{2}$ taneleri XRD ve SEM analizleri ile belirlenmiştir. Filmler için dejenere n-tipi iletkenlik özelliği elektriksel ve optiksel karakterizasyonlar ile belirlenmiştir. Özdirenç ve tabaka direnci değerleri ilk olarak ağırlıkça \% $1.5 \mathrm{Sb}$ içeriği ile azalmıştır ve sonra bu değerler daha fazla Sb içeriği ile artmıştır. Fakat taşıyıcı konsantrasyonu ağırlıkça \% 2.5 Sb içeriği ile artmıştır, sonra ise \% $3.5 \mathrm{Sb}$ içeriği ile azalmaya başlamıştır. Numunelerin optik bant aralığı $\mathrm{Sb}$ katkılama ile azalma eğilimindedir. Bu çalışmada elde edilen sonuçlardan $\mathrm{Sb}$ katkılı kalay oksit ince filmlerin optoelektronik uygulamalarda kullanılabileceği söylenebilir.
\end{abstract}

Anahtar Kelimeler: Isıl püskürtme, $\mathrm{SnO}_{2}$, Sb-katkılama, Elektriksel özellikler.

\section{INTRODUCTION}

Tin dioxide (stannic oxide) has excellent features of a broad band-gap of well-nigh $3.6 \mathrm{eV}$ [1], highrise optical visible transmission, infrared reflection and electrical conduction [2], small expense, superior mechanic strength and insistence under peripheral influences $[3,4]$. The stannic oxide is a dielectric material, but the non-stoichiometry resulted from $\mathrm{O}$ vacancies or $\mathrm{Sn}$ interstitials brings an n-type conductivity property [2]. These features make it useful for solar cells, li-ion batteries, light emitting diodes, gas sensors, architectural windows $[5,6]$. The properties of stannic oxide $\left(\mathrm{SnO}_{2}\right)$ can be tailored by doping with extrinsic atoms $(\mathrm{Nd}, \mathrm{W}$, $\mathrm{Sb}, \mathrm{V}, \mathrm{Ta}, \mathrm{Mo}, \mathrm{Nb}, \mathrm{F})$. The antimony ( $\mathrm{Sb}$ ) has $5+$ oxidation state. When $\mathrm{Sb}^{5+}$ is substituted with $\mathrm{Sn}^{4+}$ or $\mathrm{Sb}^{5+}$ places on interstitial sites, it brings about an 
additional free electron to tin oxide structure and it causes an increase in optical transmission and electrical conduction of $\mathrm{SnO}_{2}$ [7]. The ionic radii of $\mathrm{Sb}^{5+}(62 \AA)$ is close to one of $\mathrm{Sn}^{4+}$ (71 $\AA$ ) [8], and their substitution do not bring about structural imperfections, which indicates $\mathrm{Sb}$ is an appropriate additive for tin oxide. Sb-incorporated stannic oxide thin layers are probably coated with many techniques such as sputtering, hydrothermal method, sol-gel coatings, chemical vapor deposition, pulsed lased deposition, and spray pyrolysis. The spray pyrolysis is an inexpensive, easy and effective [7, 9, 10]. A variety of works have been already reported on the inquiring of features of spray coated $\mathrm{Sb}$-introduced $\mathrm{SnO}_{2}[8,11$ 21] and it was observed Sb-content greatly healed the features of stannic oxide. Although there are many studies on Sb-incorporated $\mathrm{SnO}_{2}$, the electrical characterization results in the present study make the study very important owing to very lower resistivity and sheet resistance values than ones in the literature. For this work, the impact of Sb-content on the crystalline, surface structure, electrical and optical features of stannic oxide is inquired.

\section{MATERIALS AND METHODS}

0.5 wt. $\%, 1.5$ wt. $\%, 2.5$ wt. $\%$, and 3.5 wt. $\%$ Sbincorporated stannic oxide thin layers were coated on the glass substrates with spray pyrolysis. The substrate temperature $\left(520{ }^{\circ} \mathrm{C}\right)$, the nozzle and substrate distance $(40 \mathrm{~cm})$, the flow rate of carrier air $(1.25 \mathrm{ml} /$ minute $)$, the amount of spray solution (50 ml) have been kept constant. Tin (II) chloride dehydrate $\left(\mathrm{SnCl}_{2} \cdot 2 \mathrm{H}_{2} \mathrm{O}\right)$ and antimony (III) chloride salts solved in methanol and propane-2-ol solvents, respectively, and small amount of $\mathrm{HCl}$ was added into solutions. When the solutions got ready, they were pulverized on the glass substrates. The color of samples changed from light blue to dark one with Sb-content.

The crystalline structure of samples were characterized by X-Ray Diffraction (XRD) measurements with a Rigaku miniflex diffractometer with $\mathrm{CuK}_{\alpha}$ radiation $(\lambda=0.15418$ $\mathrm{nm})$. The surface of coatings was examined with Scanning Electron Microscope (Nova nano SEM) and atomic force microscope (Nanomagnetic Instruments AFM). The thickness of films were identified to be about $1.66 \mu \mathrm{m}$ with a crosssectional SEM picture. The electric conductivity and optical studies were made with Hall measurements and UV-VIS (PerkinElmer, Lambda 35) spectrophotometer.

\section{RESULTS AND DISCUSSIONS}

\subsection{Crystalline Features}

The crystalline structure of Sb-incorporated $\mathrm{SnO}_{2}$ thin films have been inquired with XRD plots shown in Fig. 1. It has been determined the whole samples are polycrystalline with $\mathrm{SnO}_{2}$ tetragonal structure (JCPDS card no: 41-1445). The preferential orientation is (301) peak for $0.5,1.5$, and 2.5 wt. \% Sb-incorporated $\mathrm{SnO}_{2}$, and this direction changes to (200) with more Sb-content. The (301) and (200) preferential directions have been also found for undoped and $\mathrm{Sb}$-incorporated $\mathrm{SnO}_{2}$ films [13, 17]. The Sb-incorporated $\mathrm{SnO}_{2}$ grains oriented along these directions to have minimum interfacial energy. In the present study, it can be concluded that precursor solution content affects the preferential orientation. For all samples, the observed other peaks are (110), (101), (211), (220), (310), and (321). The interplanar distance (d) values have been calculated by Bragg's law and they have been checked with the standard ones (in Table I). The lattice constants have been identified with equation [2].

$$
\frac{1}{d^{2}}+\left(\frac{h^{2}+k^{2}}{a^{2}}\right)+\frac{l^{2}}{c^{2}}
$$




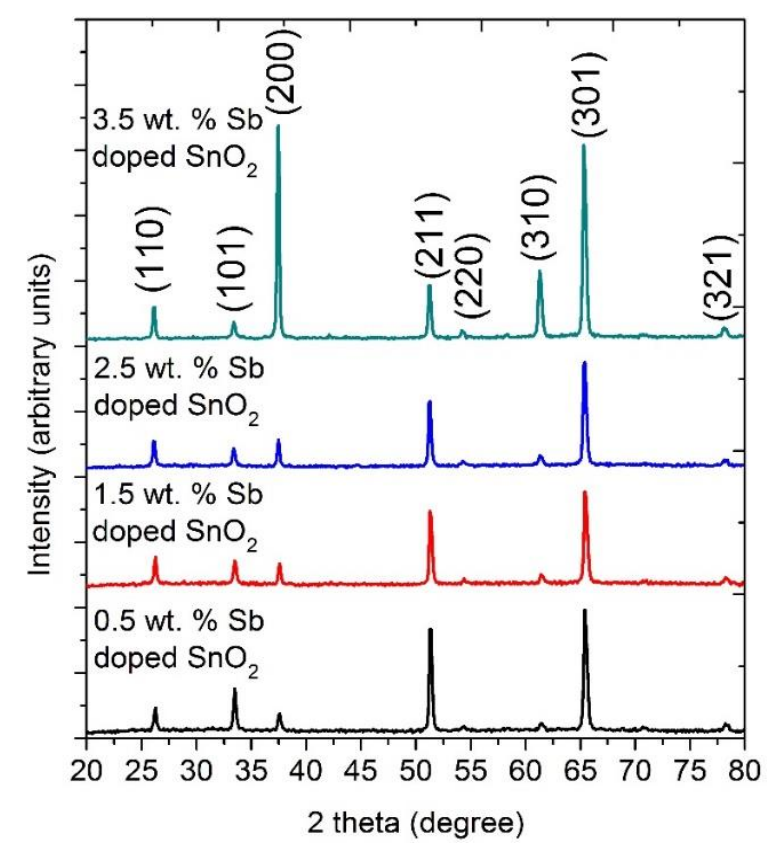

Figure 1. The $\mathrm{XRD}$ graphs of $\mathrm{Sb}$ incorporated $\mathrm{SnO}_{2}$ thin films.

These values have been comparable with the standard ones of $a=b=0.47382 \mathrm{~nm}$ and $c=0.31871$ $\mathrm{nm}$. The average crystallite size of Sb-incorporated films have been determined for the most striking peak with Scherer's formula by using $\beta$ - FWHM (full width at half of the peak maximum) [22].

\subsection{Surface properties}
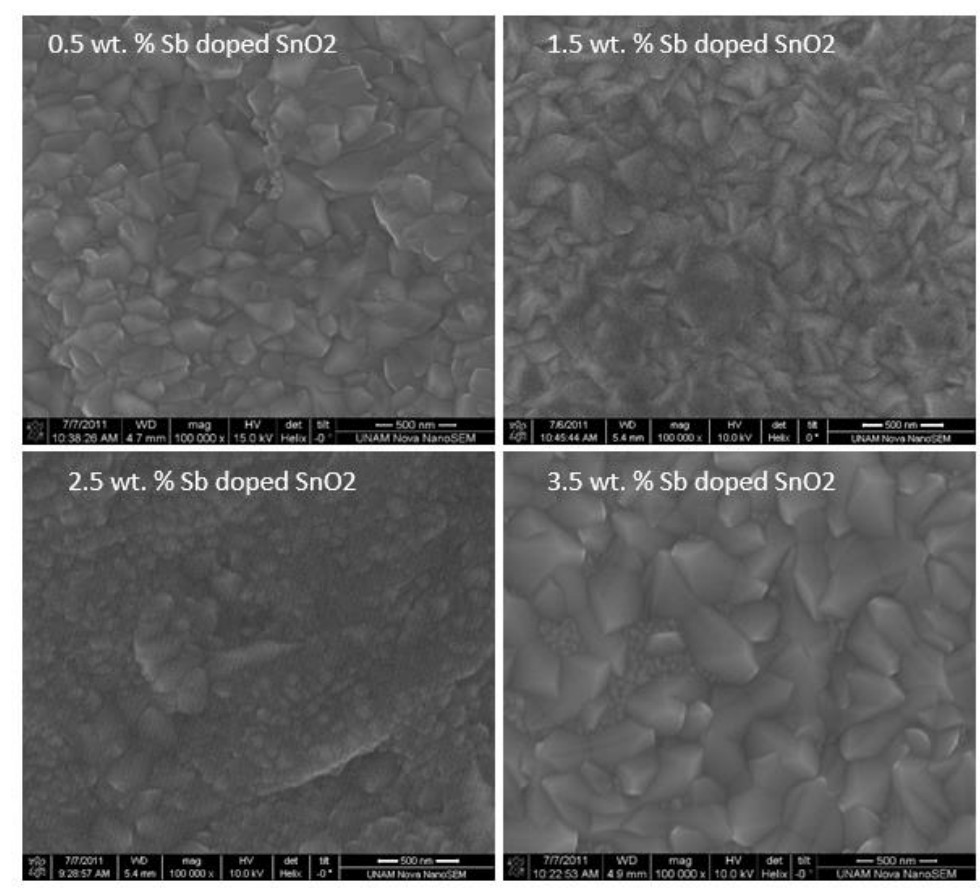

Figure 2. The SEM pictures of Sb-incorporated $\mathrm{SnO}_{2}$ thin films.
$\mathrm{D}=\frac{0.9 \lambda}{\beta \cos \theta}$

The $\mathrm{D}$ values have been identified to be $30.19 \mathrm{~nm}$, $28.76 \mathrm{~nm}, 29.37 \mathrm{~nm}$, and $34.12 \mathrm{~nm}$ for $0.5 \mathrm{wt}$ \%, 1.5 wt. $\%, 2.5$ wt. $\%$, and 3.5 wt. \% Sb-incorporated $\mathrm{SnO}_{2}$ films. The micro-strain $(\varepsilon)$ for samples is identified by relation [7].

$\varepsilon=\left(\frac{1}{\sin \theta}\right)\left[\left(\frac{\lambda_{x}}{D}\right)-(\beta \cos \theta)\right]$

$\varepsilon$ value of 0.5 wt. $\% \mathrm{Sb}$-incorporated stannic oxide initially increases from $3.70 \times 10^{-3}$ to $3.90 \times 10^{-3}$ with 1.5 wt. \% Sb-content, then it decreases to the value of $3.71 \times 10^{-3}$ for 2.5 wt. $\% \mathrm{Sb}$ and then it again increases to $5.66 \times 10^{-2}$ with more Sb-level. The density of dislocations $(\delta)$ for samples is estimated with relation [7].

$\delta=1 / \mathrm{D}^{2}$

$\delta$ values of 0.5 wt. $\%, 1.5$ wt. $\%, 2.5$ wt. $\%$, and 3.5 wt. \% Sb-incorporated $\mathrm{SnO}_{2}$ are determined to be $1.09 \times 10^{15}$ lines $/ \mathrm{m}^{2}, 1.20 \times 10^{15}$ lines $/ \mathrm{m}^{2}, 1.16 \times 10^{15}$ lines $/ \mathrm{m}^{2}$, and $8.59 \times 10^{14}$ lines $/ \mathrm{m}^{2}$, respectively. 
The surface structures of Sb-incorporated $\mathrm{SnO}_{2}$ samples are investigated with SEM and AFM studies. The SEM pictures in Fig. 2 show the particle size initially decreases with Sb level until 2.5 wt. \% Sb doping content then it increases with 3.5 wt. \% Sb doping. The particle structure resembles pyramidal and polyhedron shapes for $0.5,1.5$, and 3.5 wt. $\%$ Sb doped $\mathrm{SnO}_{2}$. The particle structure changes to small dense shapes and also
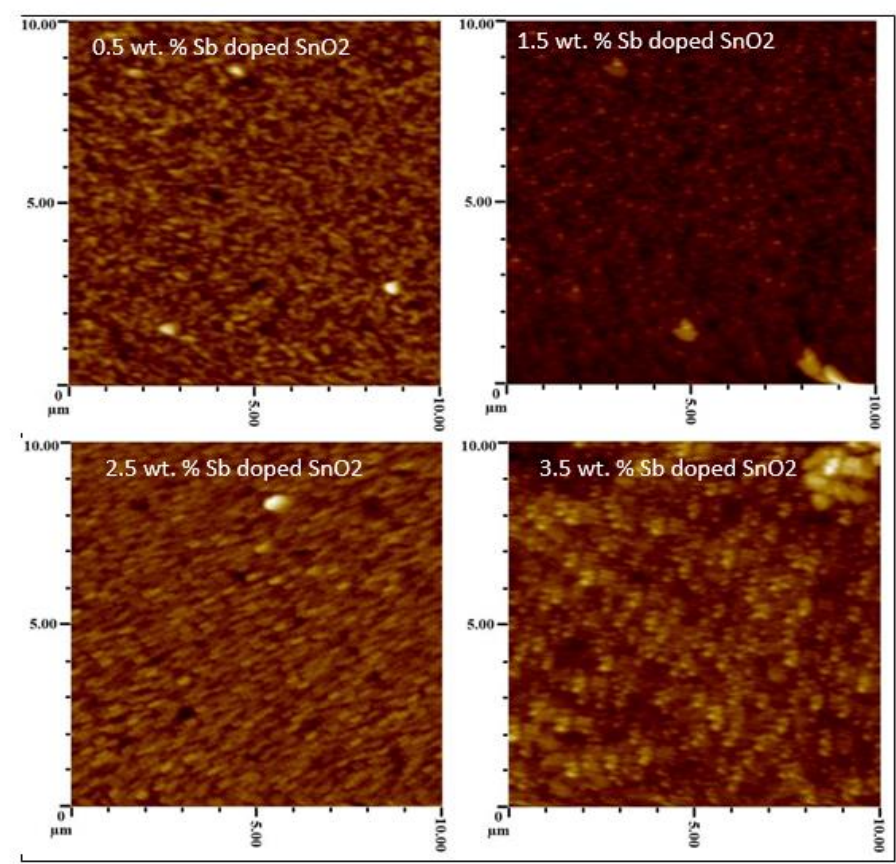

Figure 3. $2 \mathrm{D}$ AFM images of Sb-incorporated $\mathrm{SnO}_{2}$ thin films.

non-homogenous particle distribution forms with 2.5 wt. \% Sb content. As indicated by Smith et al. [23], the change in the film surface structure may be resulted from different spraying solutions. These morphologies have been also found in earlier studies [7, 12, 24].

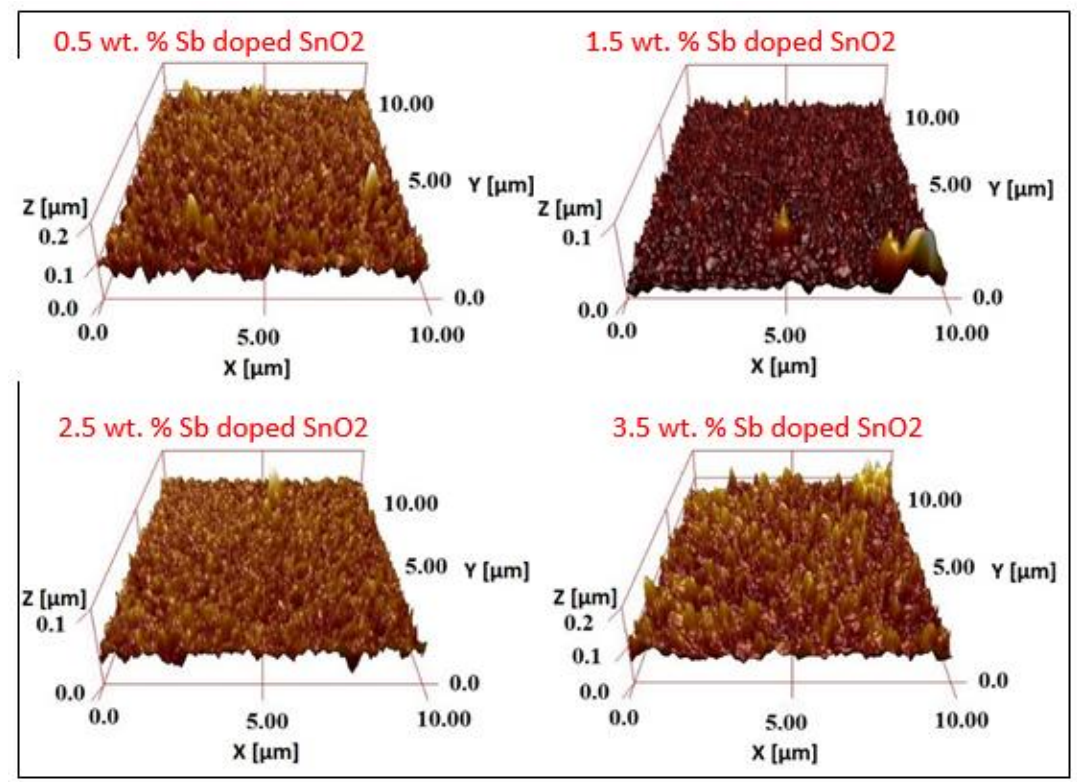

Figure 4. 3D AFM images of Sb-incorporated $\mathrm{SnO}_{2}$ thin films. 
The 2D and 3D AFM pictures in Fig. 3 and Fig. 4 reveals the grains are homogenously distributed on the surfaces of films. These results suggest that surface structure of films are highly influenced with Sb-contribution level.

\subsection{Electrical features}

The electrical features of Sb-incorporated $\mathrm{SnO}_{2}$ samples are inquired by Hall measurements. The electrical measurements indicate n-type electrical conductivity. The resistivity $(\rho)$, sheet resistance $\left(R_{s}\right)$, carrier concentration $(n)$, and mobility $(\mu)$ values are given in Table III. The resistivity and sheet resistance values of 0.5 wt. $\%$ Sbincorporated $\mathrm{SnO}_{2}$ thin film initially decrease from the values of $1.80 \times 10^{-3} \Omega . \mathrm{cm}$ and $10.6 \Omega$ to the values of $1.71 \times 10^{-4} \Omega$.cm and $1.03 \Omega$ for $1.5 \mathrm{wt} . \%$ Sb-contribution content. When Sb-contribution ratio is increased, the resistivity and sheet resistance values start to increase. The carrier concentration value of $0.5 \mathrm{wt}$. \% Sb-incorporated sample increases from $5.81 \times 10^{19} \mathrm{~cm}^{-3}$ to the values of $1.34 \times 10^{20} \mathrm{~cm}^{-3}$ and $1.92 \times 10^{20} \mathrm{~cm}^{-3}$ for $1.5 \mathrm{wt} . \%$ and 2.5 wt. \% Sb-contribution levels, then decreases to the value of $5.76 \times 10^{19} \mathrm{~cm}^{-3}$ with 3.5 wt. \% Sb-content. The carrier mobility of $61.1 \mathrm{~cm}^{2}$ $\mathrm{V}^{-1} \mathrm{~s}^{-1}$ for 0.5 wt. \% Sb-contributed sample abruptly increases to the value of $266 \mathrm{~cm}^{2} \mathrm{~V}^{-1} \mathrm{~s}^{-1}$ with $1.5 \mathrm{wt}$. $\%$ Sb-content, then it starts to decreases to the value of $150 \mathrm{~cm}^{2} \mathrm{~V}^{-1} \mathrm{~s}^{-1}$ for $2.5 \mathrm{wt}$. \% Sb-doping ratio and it again increases to $237 \mathrm{~cm}^{2} \mathrm{~V}^{-1} \mathrm{~s}^{-1}$ for $3.5 \mathrm{wt}$. $\% \mathrm{Sb}$ ratio. Fermi energy $\left(E_{F}\right)$ of a degenerate n-type material is inside the conduction band (CB). This degeneracy is based on the energy difference of $\mathrm{CB}$ and Fermi level (FL). $\mathrm{E}_{\mathrm{F}}$ values of these materials is given with equation [24].

$E_{F}=\left(\frac{h^{2}}{8 m^{*}}\right)\left(\frac{3 n}{\pi}\right)^{\frac{2}{3}}$

$\left(m^{*}=0.3 \mathrm{~m}\right.$ from Ref. [21]). $\mathrm{E}_{\mathrm{F}}$ value of 0.18 for 0.5 wt. \% Sb-incorporated $\mathrm{SnO}_{2}$ initially goes up to the values of $0.32 \mathrm{eV}$ and $0.40 \mathrm{eV}$ for $1.5 \mathrm{wt} . \% \mathrm{Sb}$ and 2.5 wt. \% Sb-doped samples, then it decreases to the value of $0.18 \mathrm{eV}$ with more Sb-content. Fermi energy values of $\mathrm{Sb}$-incorporated $\mathrm{SnO}_{2}$ samples are much higher than $\mathrm{kT}(\sim 0.03 \mathrm{eV})$, which indicates degeneracy of films.

The grain size, structural imperfections, and substitution of $\mathrm{Sb}^{5+}$ by $\mathrm{Sn}^{4+}$ can cause a change in the values of $\rho, R_{s}, n$, and $\mu$ with Sb-content. The stoichiometric stannic oxide is a good dielectric, but the valance states of 4+ and 2+ of Sn may be seen as a reason for non-stoichiometry with oxygen vacancies. An increase in the carrier concentration and easy movement of carriers causes a decrement in the values of $\rho$ and $R_{s}$. In the variation of carrier concentration with Sb-content, it is expected that $\rho$ and $\mathrm{R}_{\mathrm{s}}$ values would be minimum for $2.5 \mathrm{wt}$. $\% \mathrm{Sb}$ content. The crystalline and surface analysis indicate that films are polycrystalline and the potential obstacles occurs at grain boundaries (GBs), which they obstruct passing of carriers. From SEM pictures, the grain size of $2.5 \mathrm{wt}$. Sb contributed film is very smaller than others, and this can be seen the reason for increasing sheet resistance and resistivity. For 3.5 wt. \% Sb doping content, $\mathrm{Sb}^{3+}$ ions is probably replaced with by $\mathrm{Sn}^{4+}$ and a degradation of electrical conductivity because of creation of acceptor states.

The carrier transition for a semiconductor is significant to determine scattering centers for mobility of carriers. Different scattering centers impress the mobility and the conductivity of the material. The GBs are effective for movement of carriers and negative charged $\mathrm{GBs}$ of $\mathrm{SnO}_{2}$ bring about obstacles for carriers. In this model, an increment of grain size reduce GB scattering owing to a small number of GBs [25]. When the mean path $(l)$ values of electrons are comparable with the crystalline size, GBs are very effective. The $l$ values are identified with equation [2]

$l=\left(\frac{\mathrm{h}}{2 \mathrm{e}}\right)\left(\frac{3 \mathrm{n}}{\pi}\right)^{\frac{1}{3}} \mu$

The mean path values of 0.5 wt. $\%, 1.5$ wt. $\%, 2.5$ wt. \%, and 3.5 wt. \% Sb-doped $\mathrm{SnO}_{2}$ films are calculated as $42.18 \mathrm{~nm}, 24.26 \mathrm{~nm}, 15.42 \mathrm{~nm}$, and $16.29 \mathrm{~nm}$, respectively. The crystallite size values determined from XRD analysis are compatible 
with these and the grain boundaries are effective for mobility. In addition to GBs, phonons, dopants, and structural imperfections [24] can be effective for limiting carrier movement. The resistivity and sheet resistance values are very low when they are compare with ones for spray deposited $\mathrm{Sb}$ doped $\mathrm{SnO}_{2}$ films earlier studies [11, 15, 17, 19].

\subsection{Optical Properties}

The optical transmittance measurement of Sbincorporated $\mathrm{SnO}_{2}$ samples has been done with UV-VIS spectrophotometer. Transmittance (T) curves shown in Fig. 5 indicate that the transmittance values of 0.5 wt. \% Sb-introduced $\mathrm{SnO}_{2}$ thin films initially increase with $1.5 \mathrm{wt} . \% \mathrm{Sb}$ content, and then continuously decrease with more Sb-level.

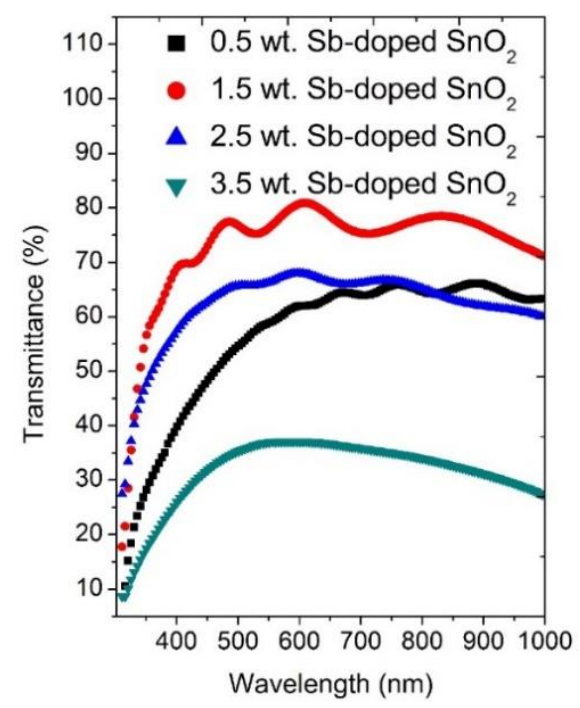

Figure 5. The optical transmittance spectra of $\mathrm{Sb}$-incorporated $\mathrm{SnO}_{2}$ thin films.

The optical band gap $\left(\mathrm{E}_{\mathrm{g}}\right)$ has been identified with following steps; initially the absorption coefficient $(\alpha)$ of a film with $d$ thickness has been determined with equation [2]

$\alpha=\ln (1 / \mathrm{T}) / \mathrm{d}$

then $E_{\mathrm{g}}$ has been determined with equation

$\alpha \mathrm{h} v=\mathrm{A}\left(\mathrm{h} v-\mathrm{E}_{\mathrm{g}}\right)^{1 / 2}$ where $\mathrm{h} v$ and $\mathrm{A}$ are photon energy and the constant. By plotting $(\alpha h v)^{2}$ versus $h v$, the $E_{g}$ values are found to be $3.94 \mathrm{eV}, 3.88 \mathrm{eV}, 3.80 \mathrm{eV}$, and $3.55 \mathrm{eV}$ for 0.5 wt. $\%, 1.5$ wt. $\%, 2.5$ wt. $\%$, and 3.5 wt. $\%$ Sb-contributed $\mathrm{SnO}_{2}$ thin films, respectively. As seen from these values, $\mathrm{Eg}$ value continuously decreases with $\mathrm{Sb}$ content.

The optical band gap of $\mathrm{SnO}_{2}$, which is one of degenerate semiconductors, is related to transition of electron from valance band (VB) to Fermi level (FL) by light [7]. The filled states between Fermi level and conduction band (CB) minimum prohibits inter-conduction-band absorption. Dopant atoms introduces the electrons into $\mathrm{CB}$ and FL rises further into $\mathrm{CB}$, which is known to be Moss-Burstein (MB) sliding [26]. The alteration of $\mathrm{n}$ with $\mathrm{Sb}$-contribution indicated that a bang gap widening would be expected with $2.5 \%$ wt. Sbcontent because of increasing the number of free carriers. But, besides the MB effect, nonstoichiometry, structural imperfections, heavy doping, and electronic transitions between $\mathrm{Sb}^{5+}$ and $\mathrm{Sb}^{3+}$ have an important effect on the changing optical band gap of $\mathrm{SnO}_{2}$ [7, 26, 28]. In the present study, the most important effect can be an increasing density of blue color with $\mathrm{Sb}$ content resulted from electronic transitions between $\mathrm{Sb}^{5+}$ and $\mathrm{Sb}^{3+}$ [28], which is indicated in the experimental section. 

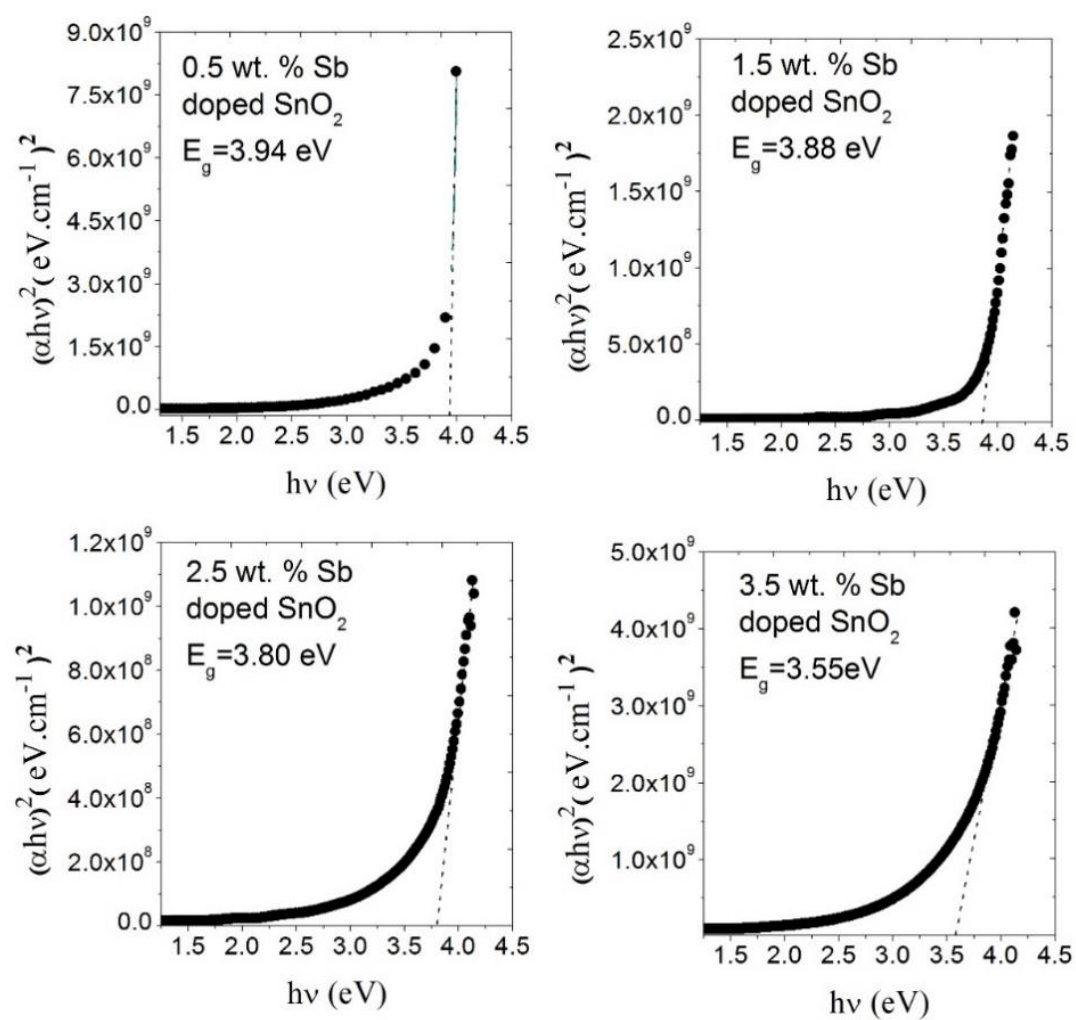

Figure 6. $(\alpha \mathrm{h} v)^{2}$ versus $\mathrm{h} v$ spectra of $\mathrm{Sb}$-incorporated $\mathrm{SnO}_{2}$ thin films.

\section{CONCLUSION}

The impact of Sb-contribution on the crystalline, surface morphology, electric and optic features of $\mathrm{SnO}_{2}$ deposited with spray pyrolysis has been inquired. The characterizations have been made by means of x-ray diffraction, scanning electron and atomic force microscopes, ultraviolet/visible spectrophotometer, and Hall measurements. The XRD analysis has revealed that the films were polycrystalline tetragonal stannic oxide with (301) and (200) preferential orientations. The SEM and AFM observations have indicated the morphology of films has been changed with Sb-contribution. The electrical characterization suggested high electrical conductivity for $\mathrm{Sb}$-incorporated $\mathrm{SnO}_{2}$ films at certain-amount of $\mathrm{Sb}$. The optical band gap of films has decreased with Sb-content.

\section{REFERENCES}

[1]. Babu B., Kadam A.N., Ravikumar R.V.S.S.N., Byon C., Enhanced visible light photocatalytic activity of $\mathrm{Cu}$-doped $\mathrm{SnO}_{2}$ quantum dots by solution combustion synthesis, J. Alloy. Comp. 703 (2017) 330336.

[2]. Turgut G., Effect of Ta doping on the characteristic features of spray-coated $\mathrm{SnO}_{2}$, Thin Solid Films 594 (2015) 56-66.

[3]. Bhatnagar M., Dhall S., Kaushik V., Kaushal A., Mehta B.R., Improved selectivity of $\mathrm{SnO}_{2}$ :C alloy nanoparticles towards $\mathrm{H}_{2}$ and ethanol reducing gases; role of $\mathrm{SnO}_{2}: \mathrm{C}$ electronic interaction, Sensors and Actuators B 246 (2017) 336-343.

[4]. Chandra S., George G., Ravichandran K., Thirumurugan K., Influence of simultaneous cationic (Mn) and anionic (F) doping on the magnetic and certain other properties of $\mathrm{SnO}_{2}$ thin films, Surfaces and Interfaces 7 (2017) $39-46$

[5]. Lian X., Li Y., Tong X., Zou Y., Liu X., An D., Wang Q., Synthesis of Ce-doped $\mathrm{SnO}_{2}$ nanoparticles and their acetone gas sensing properties, App. Surf. Sci. 407 (2017) 447455. 
[6]. Gao F., Li Y., Zhao Y., Wan W., Du G., Ren X., Zhao H., Facile synthesis of flower-like hierarchical architecture of $\mathrm{SnO}_{2}$ nanoarrays, J. Alloy. Comp. 703 (2017) 354-360.

[7]. Turgut G., Keskenler E.F., Aydın S., Sönmez E., Doğan S., Düzgün B., Ertuğrul M., Effect of $\mathrm{Nb}$ doping on structural, electrical and optical properties of spray deposited $\mathrm{SnO}_{2}$ thin films, Superlattices and Microstructures 56 (2013) 107-116.

[8]. Elangovan E., Ramamurthi K., A study on low cost-high conducting fluorine and antimonydoped tin oxide thin films, App. Surf. Sci. 249 (2005) 183-196.

[9]. Ynineb F., Attaf N., Aida M.S., Bougdira J., Bouznit Y., Rinnert H., Morphological and optoelectrical study of $\mathrm{ZnO}: \mathrm{In} / \mathrm{p}-\mathrm{Si}$ heterojunction prepared by ultrasonic spray pyrolysis, Thin Solid Films 628 (2017) 36-42.

[10].Menaka S. M., Umadevi G., Manickam M., Effect of copper concentration on the physical properties of copper doped $\mathrm{NiO}$ thin films deposited by spray pyrolysis, Material Chemistry and Physics 191 (2017) 181-187.

[11].Babar A.R., Shinde S.S., Moholkar A.V., Bhosale C.H., Kim J.H., Rajpure K.Y., Physical properties of sprayed antimony doped tin oxide thin films: The role of thickness, Journal of Semiconductors 32 (2011) 8p.

[12].Babar A.R., Shinde S.S., Moholkar A.V., Bhosale C.H., Kim J.H., Rajpure K.Y., Sensing properties of sprayed antimony doped tin oxide thin films: Solution molarity, J. Alloy. Comp. 509 (2011) 3108-3115.

[13].Babar A.R., Shinde S.S., Moholkar A.V., Bhosale C.H., Kim J.H., Rajpure K.Y., Structural and optoelectronic properties of antimony incorporated tin oxide thin films, J. Alloy. Compd. 505 (2010) 416-422.

[14].Bisht H., Eun H.T., Mehrtens A., Aegerter M.A., Comparison of spray pyrolyzed FTO, ATO and ITO coatings for flat and bent glass substrates, Thin Solid Films 351 (1999) 109114.

[15].Elangovan E., Ramamurthi K., Effect of substrate temperature on electrical and optical properties of spray deposited $\mathrm{SnO}_{2}: \mathrm{Sb}$ Thin Films, J. Opt. Adv. Mater. 5 (2003) 415-420.

[16].Elangovan E., Ramamurthi K., Studies on optical properties of polycrystalline $\mathrm{SnO}_{2}: \mathrm{Sb}$ thin films prepared using $\mathrm{SnCl}_{2}$ precursor, Cryst. Res. Cryst. Tech. 38 (2003) 779-784.

[17].Elangovan E., Ramesh K., Ramamurthi K., Studies on the structural and electrical properties of spray deposited $\mathrm{SnO}_{2}: \mathrm{Sb}$ thin films as a function if substrate temperature, Solid State Commun. 130 (2004) 523-527.

[18].Elangovan E., Shivashankar S.A., Ramamurthi K., Studies on structural on structural and electrical properties of sprayed $\mathrm{SnO}_{2}: \mathrm{Sb}$ films, J. Crys. Growth 276 (2005) 215-221.

[19].Ravichandran K., Philominathan P., Fabrication of antimony doped tin oxide (ATO) films by an inexpensive, simplified spray technique using perfume atomizer, Mater. Lett. 62 (2008) 2980-298.

[20].Ravichandran K., Phiominathan P., Analysis of critical doping level of sprayed antimony doped tin oxide films, J. Mater. Sci: Mater. in Elec. 22 (2011) 158-161.

[21].Thangaraju B., Structural and electrical studies on highly conducting spray deposited fluorine and antimony doped $\mathrm{SnO}_{2}$ thin films from $\mathrm{SnCl}_{2}$ precursor, Thin Solid Films 402 (2002) 71-78.

[22].Turgut G., Duman S., Özçelik F.S., Sonmez E., Gurbulak B., An investigation of $\mathrm{Zn} / \mathrm{ZnO}: \mathrm{Al} / \mathrm{p}-\mathrm{Si} / \mathrm{Al}$ heterojunction diode by sol-gel spin coating technique, J. Sol-Gel Sci. Technol. 71 (2014) 589-596.

[23].Smith A., Laurent J. M., Smith D. S., Bonnet J. P., Clemente R. R., Relation between solution chemistry and morphology of $\mathrm{SnO}_{2}-$ based thin films deposited by a pyrosol process, Thin Solid Films 266 (1995) 20-30.

[24].Turgut G. and Keskenler E.F., The characteristic investigation of spray coated $\mathrm{W}$ incorporated in oxide thin films, Moscow University Physics Bulletin 71 (2016) 105113.

[25].Kazmerski L.L., Polycrystalline and Amorphous Thin Films and Devices.New York: Academic Press, 1980.

[26].Turgut G. and, Sönmez E., Synthesis and characterization of Mo doped $\mathrm{SnO}_{2}$ thin films with spray pyrolysis, Superlattices and Microstructures 69 (2014) 175-186.

[27]. Whitney J.E. and Davidson N., A Spectrophotometric Investigation of the Interaction between Antimony (III) and $(\mathrm{V})^{1 \mathrm{a}, \mathrm{b}, \mathrm{c}}$ in Hydrochloric Acid Solutions, J. American Chem. Soc. 71 (1949) 3809-3816.

[28].Jung D. W. and Park D. W., Synthesis of nano-sized antimony-doped tin oxide (ATO) particles using a DC arc plasma jet, App. Surf. Sci. 255 (2009) 5409-5413. 